UDK: 314.04-053.9:316.4

Izvorni naučni rad

Primljeno: 8. 9. 2020.

Prihvaćeno za štampu: 23. 11. 2020.

Dr. sc. Sena Družić, docent

Vlada Unsko-sanskog kantona

E-mail:sena_druii@@yahoo.ca

\title{
DEMOGRAFSKO STARENJE STANOVNIŠTVA I SOCIJALNA POLITIKA
}

\section{Sažetak}

Demografija istrą̌uje i proučava a akonitosti i pravilnosti u biološkom i migracionom kretanju stanovnistva te promjene u demografskim strukturama, $i$ utvrduje medusobne odnose kretanja stanovnistva s drugim drustvenim i ekonomskim pojavama. U ovom naučnom radu, za predmet istraそ̌ivanja uzeta je starija populacija stanovnistva, koja čini specifičnu drustvenu grupu cije su potrebe, proistekle i₹,procesa starenja, a javljaju se u oblasti socijalne politike, kao organizovano, aktivno angažovanje drustvene rajednice u obezbjeđivanju zivotnih uslova, odnosno socijalne sigurnosti starijih osoba. Sam cilj rada je spoznati koliko migraciona kretanja stanounistva, $i$ to na lokalnom nivou (ruralno-urbanom), iseljavanja cijelib porodica u inozemstvo, kao $i$ tranzit stanovnika s Bliskog istoka i drugih zemalja, kroz našu zemlju, utječu na promjenu demografske strukture bosanskohercegovačkog stanovnistva. U radu je korištena metoda analize sadř̌aja s raspoloživim podacima, na predmetnu temu. $\mathrm{Na}$ osnovu spoznaja, do kojih se došlo u radu, iqvodi se qaključak, da je iæraženo smanjenje broja novorodene djece, a povećanje broja starih osoba, kao i migracija stanovnistva koja se dešava u našoj dř̌avi. Sve navedeno zabtijeva empirijsko istră̌ivanje koje bi se provelo na cijelom području Bosne $i$ Hercegovine, a sve s ciljem spoznaje urroka, zbog kojih dolari do migracije stanovnistva, te posljedica koje će migracije ostaviti na demografsku strukturu stanovništva i socijalnu politiku dř̌ave.

Ključne riječi: demografija, starenja, starenje stanovnistva, socijalna politika 


\section{UVOD}

Starenje stanovništva jedno je od važnijih pitanja budućnosti i društvenog razvoja velikog broja zemalja. Utjecaj i posljedice relativno brzog povećanja udjela stare populacije u društvu očituje se u najvažnijim sektorima, kao što su zdravstvo, socijalna zaštita i drugim. Dakle, ljudski faktor - stanovništvo, starosna struktura, radna sposobnost, natalitet i mortalitet, predstavljaju osnovne pokazatelje stanja i odnosa, mogućnosti ekonomskog razvoja, iz čega proizilaze i ciljevi socijalne politike države. Da bi se ciljevi socijalne politike realno isplanirali, a njihova realizacija donijela najbolje rezultate za stanovništvo Bosne i Hercegovine, neminovno se postavlja potreba za naučnim istraživanjem o starenju stanovništva i direktne pomoći države, putem socijalne politike, grupama pod rizikom kao što su stare osobe. Ovaj naučni rad ima za cilj istražiti demografsko starenja stanovništa i svjesnu praktičnu društvenu djelatnost, koja se bavi životnim i radnim uslovima ljudi, u Bosni i Hercegovini. Predmet istraživanja su utjecaji migracija i povećanja broja starijih osoba, na demografsku sliku bosanskohercegovačkog društva.

Kroz strukturu rada definirani su pojmovi demografije, starenja, starenje stanovništva i socijalne politike, do kojih se došlo, kroz naučne spoznaje o predmetnim pojmovima. Kao prvo posebno poglavlje autor obrađuje demografski razvoj i starenje stanovništva, iz razloga što je stanovništvo jedne zemlje nositelj ekonomskog razvoja, a njegovo starenje daje znak većeg planiranja sredstava i usluga u oblasti socijalne politike koji je posebno i opisan u poglavlju učešće socijalna politika $u$ zaštiti starih osoba. U predmetnom poglavlju, postavlja se podnaslov dosadašnjih istraživanja, koja se najvećim dijelom odnose na zemalje iz regije. U naučnom radu, kroz poglavlje dva (2) obrađuje se povezanost demografskog starenja stanovništva i socijalne politike, jer s povećanjem broja starih osoba, odlaskom mladih osoba iz Bosne i Hercegovine, zahtijevat će se veće uključenje u oblast socijalne politike. U navedenom poglavlju, kao podnaslovi obrađuju se teme migracija stanovništa kao važan faktor demografskih promjena, te donošenje dokumenata za strateški razvoj naše zemlje. Država čini napore, donosi strategije razvoja i akcione planove, za određeni vremenski period, ali se postavlja pitanje, ko će te aktivnosti sprovesti, ako nam mladi, stručni kadar, odlazi u druge zemlje. U radu se 
neminovno izvodi zaključak, potrebe istraživanja o demografskom starenju stanovništva i potrebama socijalne politike, a koji bi se realizirao i uz aktivno učešće nezavisnih medija.

\section{DEFINISANJE DEMOGRAFSKOG STARENJA STANOVNIŠTVA I SOCIJALNE POLITIKE}

\subsection{Pojmovno određenje}

U stručnoj literaturi, ali i u praktičnoj, svakodnevnoj upotrebi, pojmovi demografija i socijalna politika, različito se tumače, razumiju, definišu i upotrebljavaju što neminovno stvara teškoće, ne samo u sporazumijevanju različitih profila stručnjaka u praksi, nego i u teorijskom određenju demografije i socijalne politike, kao naučnih disciplina. U naslovu teme, kao ključne riječi naveli smo pojmove, koje ćemo definisati, na osnovu dosad naučno objavljenih definicija.

\subsubsection{Demografija}

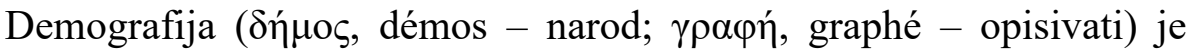
društvena nauka o stanovništvu. Ovaj naziv je prvi upotrijebio belgijski statističar Akil Giljar (Achille Guillard) 1855. godine (Šarić, H., Družić, S. i dr., 2016). Demografija je interdisciplinarna nauka povezana s matematikom i statistikom, ekonomijom, sociologijom, medicinom i epidemiologijom, psihologijom, antropologijom i biologijom. Ova nauka ima relativno kratku historiju, koja intenzivno počinje 1798. godine, kada je izdana knjiga An Essay on the Principle of Population (Esej o principima stanovništva) Tomasa Maltusa.

Po naučniku A. Guillard (1799-1876) u djelu Elementi humane statistike ili komparativna demografija (Pariz 1855. preuzeto Šarić, H., Družić, S. i dr., 2016) definicija glasi "demografija je po predmetu istraživanja sinonim zakona o stanovništvu. Zakon stanovništva u najširem smislu riječi znači zakon ili cjelokupnost zakona prema kojima čovječanstvo ostvaruje svoj napredak, najprije brojčano, a kasnije u pogledu obrazovanja, moralnih vrijednosti i snaga, kao i standarda". Dalje, A. Guillard je demografiju definisao kao "prirodnu i društvenu nauku ljudske vrste", a u užem smislu kao "matematičko znanje o 
stanovništvu, o njegovim opštim kretanjima, o njegovom fizičkom, građanskom, intelektualnom i moralnom stanju".

Drugi autori davali su najčešće užu definiciju, i po njima predmet demografskih izučavanja obuhvata, prije svega, prirodno (smrtnost i fertilitet stanovništva) i mehaničko (migracije) kretanje stanovništva, kao i opisivanje nekih osnovnih stanja stanovništva (spolni i starosni sastav, struktura po bračnom stanju itd.).

Danas u literaturi dolazi u većoj mjeri do izražaja šire shvatanje demografije i njenog predmeta. Pojam demografije vezuje se za demografski razvitak, a demografski razvitak je kompleksan proces koga čine prirodno i mehaničko kretanje stanovništva (natalitet, fertilitet, smrtnost i migracije), kao i promjene u demografskim strukturama (biološkim, socio-ekonomskim i intelektualnim). Između kretanja i struktura stanovništva postoji obostrana međusobna povezanost, koja se ogleda $\mathrm{u}$ tome što komponente kretanja stanovništva utiču na strukture, i obrnuto, demografske strukture ispoljavaju svoj uticaj na natalitet i smrtnost, odnosno na preseljavanje stanovništva (Šarić, H., Družić, S. i dr., 2016).

S druge strane, komponente kretanja stanovništva kao i demografske strukture i promjene u njima uslovljene su djelovanjem brojnih činilaca: bioloških, socio-ekonomskih, ekoloških, kulturnih i socio-psiholoških. Pomenuti faktori i njihovo djelovanje ispoljavaju se različito u datim uslovima društvenog i ekonomskog razvoja, što znači da je demografski razvitak historijski uslovljen. Drugim riječima, stanovništvo koje živi na izvjesnom stupnju društvenog i ekonomskog razvoja pokazivat će u pogledu demografskog razvitka pravilnosti i zakonomjernosti koje su svojstvene datom stepenu razvoja. Predmet demografije je stanovništvo koje živi na nekoj teritoriji i koje se mijenja u pogledu svojih obilježja po zakonomjernostima svojstvenim za izvjesno historijsko razdoblje. Stanovništvo, pak, predstavlja skup lica, ljudi, na nekoj teritoriji koji se razlikuje od samih individua, mada je od njih sastavljen. Po današnjem, širem gledištu, demografija izučava, njegovo kretanje, razmještaj i druge pojave, kao i njegove strukture koje se zasnivaju na individualnim karakteristikama pojedinaca (Šarić, H., Družić, S. i dr., 2016). 


\subsubsection{Starenje}

Starenje se u našem jeziku koristi u dva značenja i to u užem i u širem smislu. U širem smislu, starenje započinje još od samog začeća i bespovratni je proces koji se sastoji iz dvije faze:

- prva faza je faza rasta i razvoja organizma i funkcija,

- druga faza koja je obilježena propadanjem organizma i slabljenjem njegovih funkcija.

Pod starenjem se podrazumijeva proces tokom kojeg se događaju promjene $u$ funkciji organizma $u$ životnoj dobi čovjeka. Na individualnom planu, pojam, ,starenje“ može da se odnosi na biološki proces, prelazne faze i promjene kroz koje prolazi individua u kasnijim životnim fazama, ili na dobrobit, u smislu fizičkog i duševnog zdravlja, ekonomskih uslova života, rada i odmora onih $\mathrm{u}$ poodmaklim godinama, čiju prekretnicu predstavlja 60. ili 65. godina života. Na društvenom planu ova riječ može označavati demografske procese koji obilježava dio stanovništva u starijem dobu, kao i socio-ekonomske i kulturne posljedice po društvo, koje prolazi kroz promjene u starosnoj strukturi (Šarić, H., Družić, S. i dr. 2016).

\subsubsection{Starenje stanovništa}

Proces starenja stanovništva ili demografskog starenja stanovništva, za razliku od individualnog, podrazumijeva određene demografske kriterije. Kao što je individualni proces starenja čovjeka određen biloškim promjenama, proces starenja stanovništva određen je demografskim promjenama, kao i kriteriji prema kojima se ovaj proces određuje. Na demografsko starenje najviše utječe pad nataliteta (tzv. dejuvenilizacija ili „starenje odozdo”), povećanje udjela starijih stanovnika (tzv. posijeđenje greying ili ,starenje odozgo“), te kretanje mortaliteta (Puljiz, 2005. b).

Primarni uzrok demografskog starenja je opadanje fertiliteta. Pri tome, starenje stanovništva odražava nivo fertiliteta, odnosno postoji obrnuta povezanost između stope nataliteta i proporcije starih osoba. Tako, niska natalitetna područja imaju veći udio starijeg stanovništva. U dužem procesu starenja, stanovništvo se smanjuje od 15 do 30 godina u odnosu na grupu od 30 do 49 godina, gdje je rađanje znatno rjeđe, 
što dalje smanjuje ukupni fertilitet. Smanjenje fertiliteta ubrzava proces starenja ukupnog stanovništva, jer odmah i direktno, postaje sve manji ukupan broj djece u stanovništvu. Poslije određenog vremena taj se utjecaj proširuje na sve starosne grupe. Usto ako i očekivana dužina života raste, srazmjerno njoj uvećava se broj starijih u odnosu na ukupno stanovništvo, a u strukturi starijih povećava se broj izrazito starijih osoba. Prema ovom mehanizmu, populacije s visokim natalitetom su veoma mlade $\mathrm{i}$ obrnuto, $\mathrm{s}$ niskim natalitetom, $\mathrm{u}$ poodmakloj su starosti.

Jedna od najvažnijih struktura stanovništva je dobna struktura, budući da utječe na društveno-ekonomski razvoj određene populacije. Ona je odraz razvoja stanovništva tokom duljeg vremenskog perioda (Šarić, H., Družić, S. i dr. 2016).

\subsubsection{Socijalna politika}

Pojam ,socijalne politike“ u stručnoj literaturi, prvi je uveo njemački naučnik Vilhem Haunrih Ril, 60-tih godina 19. vijeka. Od autora izdvajamo sljedeće dvije definicije:

„Socijalnu politiku možemo definirati kao svjesnu i praktičnu društvenu djelatnost, koja se bavi životnim i radnim uslovima ljudi i društvenih grupa."(Lakičević, 1991)

„Socijalna politika preovladava socijalne razlike, ublažava socijalne nejednakosti i druge negativne posljedice na tržištu. Ona potiče društvenu solidarnost i integraciju, amortizira socijalne sukobe, te omogućava normalno funkcionisanje i razvoj društva." (Puljiz, V., Bežovan, G., Šućur, Z., \& Zrinščak, S. 2000)

Dakle, država kroz praktičnu primjenu odgovarajućih mjera i akcija iznalazi načine rješavanja problema, a to se naročito odnosi na one građane koji su u stanju nemogućnosti zadovoljavanja osnovnih socijalni potreba, odnosno građana, kojima njihovi životni i radni uslovi, ne pružaju, neophodnu socijalnu sigurnost (Miković, M. 2005).

\subsection{Demografski razvoj i starenje stanovništva}

Demografski razvitak je kompleksan proces, koga čine prirodno i mehaničko kretanje stanovništva (natalitet, fertilitet, smrtnost i 
migracije), kao i promjene u demografskim strukturama (biološkim, socio-ekonomskim i intelektualnim). Između kretanja i strukture stanovništva postoji obostrana međusobna povezanost, koja se ogleda $\mathrm{u}$ tome što komponente kretanja stanovništva utiču na strukture, i obrnuto. Demografske strukture ispoljavaju svoj uticaj na natalitet i smrtnost, odnosno na preseljavanje stanovništva. S druge strane, komponente kretanja stanovništva kao i demografske strukture i promjene u njima uslovljene su djelovanjem brojnih faktora: bioloških, socio-ekonomskih, ekoloških, kulturnih i socio-psiholoških. Pomenuti faktori i njihovo djelovanje ispoljavaju se različito $u$ datim uslovima društvenog i ekonomskog razvoja, što znači da je demografski razvitak historijski uslovljen. Drugim riječima, stanovništvo koje živi na određenom stupnju društvenog i ekonomskog razvoja, pokazivat će u pogledu demografskog razvitka, pravilnosti i zakonomjernosti koje su svojstvene datom stepenu razvoja (www.ekof.bg.ac.rs).

Stanovništvo je nositelj ekonomskog razvoja, jer ono predstavlja demografski okvir za formiranje proizvodne (radne) snage koja pokreće i usmjerava sve djelatnosti u prostoru.

Ekonomski razvoj neke zemlje ima svoj, prilično jasno definiran, demografski okvir. Njega sačinjavaju četiri osnovne karakteristike demografskog razvoja:

(1) ukupno kretanje stanovništva (promjena broja stanovnika);

(2) prirodno kretanje stanovništva (natalitet/fertilitet, mortalitet, prirodna promjena);

(3) mehaničko kretanje stanovništva (emigracija/imigracija);

(4) demografske strukture (biološka, ekonomsko-socijalna i obrazovna). (Živić, D., 2003)

Ukupno kretanje stanovništva rezultat je djelovanja prirodnog i mehaničkog kretanja stanovništva i tendencija u razvoju demografskih struktura, što možemo nazvati i "unutarnjim" faktorom demografskog razvoja. Međutim, razvoj stanovništva određen je i djelovanjem brojnih "vanjskih" odrednica, među kojima se svojom važnošću ističu ekonomski, politički (osobito rat) i ostali (psihološki i drugi) faktori. S obzirom na to da je stanovništvo "izvor najbitnijeg faktora proizvodnje - radne snage" (Wertheimer-Baletić, 1999: 4), a da se radna snaga 
(aktivno stanovništvo) formira iz radnog kontingenta (radno sposobno stanovništvo) koji se nalazi pod direktnim utjecajem niza demografskih činitelja, osobito dobno-spolne strukture stanovništva, onda raščlanjenje i poznavanje procesa u razvoju biološke strukture stanovništva postaje važnim preduvjetom za ocjenu demografskih potencijala u današnjem i budućem ekonomskom razvoju države.

\subsection{Učešće socijalne politike u zaštiti starih osoba}

U sadržajima socijalne politike, značajno mjesto zauzimaju aktivnosti na osiguranju od životnih rizika koji proizlaze iz procesa starenja i problema starosti, rješavanja socijalnih protivrječnosti koji se prelamaju u životnim uslovima starih i njihovo predupređenje, kao i podsticanja i usmjeravanja porodice da se brine o svojim starim članovima domaćinstva.

Razvojem socijalne politike i uočavanjem čvrste povezanosti ekonomskog i socijalnog faktora njen predmet se po svom obimu i sadržaju proširuje na životne i radne uslove ljudi, i njihov ukupni društveni položaj. Od pojedinca - čovjeka, obim socijalne politike se proširuje na stanovništvo, od kojih posebno ističemo djecu i stare osobe.

Pored određenja životnih i radnih uslova ljudi kao univerzalnog pojma, u sadržaje socijalne politike ulaze i neke konkretne djelatnosti, kao što su: osiguranje povodom više različitih životnih rizika i teškoća, osmišljavanje socijalnih promjena, predupređenje i prevazilaženje socijalnih protivrječnosti i problema, socijalne inovacije, podsticanje i usmjeravanje socijalnog razvoja i slično (Milosavljević, M. 1990).

Neodvojivo od osnovnih pitanja o starenju stanovništva čini i pitanje porodične solidarnosti. Porodica kao najznačajnija društvena grupa $u$ životu pojedinca i društva u cjelini zauzima, shodno tome, važno mjesto i dijelove aktivnosti socijalne politike.

Mjere socijalne politike koje su rezultat aktivnosti i usluga različitih društvenih institucija i ustanova, nazivaju se često i porodičnom politikom.

U ovoj oblasti socijalne politike kojoj tek predstoji ozbiljan razvoj, također su važna pitanja vezana za porodicu starih ljudi, s obzirom na 
sve češću pojavu njene ekonomske deprivacije i socijalne izolacije. Posebno treba obratiti pažnju na promjene u brojnosti članova porodice, što predstavlja jako važan faktor $\mathrm{u}$ demografskoj strukturi stanovništava.

\subsubsection{Dosadašnja istraživanja}

Stanovništvo Evropske unije trebalo bi nastaviti stariti. Broj ljudi od 65 i više godina porast će sa $17,4 \%$ u sadašnjem trenutku, na $29,5 \%$ do 2060. godine, a onih od 80 i više godina sa $4,6 \%$ na $12 \%$ u istom razdoblju. Eurostat, starenje stanovništva objašnjava slabim natalitetom i sve većim brojem ljudi koji dožive duboku starost. Najmanje starijih (osoba) od 65 godina 2060. trebale bi imati Belgija i Danska 25\%, Luksemburg 26,4\% i Francuska 26,6\%. Kod stanovnika starijih od 80 godina, najmanje će ih biti u Cipru 9,2\%, a najbrojniji će biti u Španjolskoj 14,2\%, Italiji 14,1\% i Njemačkoj 13,5\%. Sukladno navedenom i Evropska unija se suočila s ozbiljnim demografskim problemima, koji utječu na ekonomsku i socijalnu situaciju država članica. Glavni problem je nezaposlenost mladih koja se pogoršala globalnom privrednom krizom. Situacija je posljedica složenog međudjelovanja neusklađenosti između vještina potrebnih poslodavcima i vještina koje posjeduju mladi, strukture tržišta koja može pogodovati starijim radnicima, obustavi zapošljavanja ili smanjenja zapošljavanja od strane poslodavaca kako bi prebrodili krizu, te raniji utjecaj krize na određene sektore koji zapošljavaju veći broj mladih radnika, kao proizvodnja ili građevinarstvo. Temeljna zadaća Evropske unije, je potpuni izlazak iz krize i obnova održivog razvoja da bi se poboljšala dobrobit i životni standard stanovništva. Istodobno se mora boriti s izazovima kao što su veća stopa starosne populacije, imigracije i globalizacija. Sama Unija mora uvjeriti svoje građane, da je u stanju da brani njihove interese, dok istodobno osluškuje očekivanja stanovnika drugih država koje žele postati dio Evropske unije (Bosanac 2015).

Većina socijalnih reformi provedenih u posljednjem razdoblju nastojala je smanjiti ulogu države, a ojačati individualnu odgovornost građana za vlastitu sudbinu, te ostvariti veći utjecaj civilnoga društva u socijalnoj sferi. Današnja, nacionalna država, je suočena s moćnim nadnacionalnim tržištima, posebno s tržištem kapitala. Da bi im se 
prilagodila, država nastoji smanjiti javne - dakle i socijalne - izdatke te tako privredu učiniti jačom. „U kontekstu u kojem su vlade sve svjesnije da moraju brzo reagirati na rizike, smanjujući plaće i troškove radi povećanja konkurentnosti, javlja se veliko iskušenje da se socijalna prava vide $u$ negativnom svjetlu, da se stoga istakne njihov fakultativni karakter i da se prohibiraju socijalni troškovi." (Daly, 2003., 22: preuzeto Puljiz 2005. c)

U više evropskih zemalja ovih posljednjih desetljeća bila je na djelu politika rezanja socijalnih izdataka (retrenchement) i traženja novih modela socijalne politike. Novija ispitivanja javnoga mišljenja pokazuju snažnu privrženost Evropljana vrijednostima socijalne države, kao što su solidarnost i socijalna pravda. Isto tako, neki autori upozoravaju da se u raspravama o socijalnoj politici precjenjuje utjecaj globalizacije (Ferrera, Rhodes, 2000. preuzeto: Puljiz, 2005. c). Međutim, neovisno o razlikama u stavovima, među analitičarima vlada prilično visok stupanj saglasnosti oko toga, da se u posljednjem razdoblju promijenio karakter socijalnih rizika i hijerarhija ciljeva socijalne politike. To je utjecalo na promjenu karaktera i smjera državne intervencije u socijalnoj sferi. Drugim riječima, ključni demografski procesi, uključujući promjene u porodici, zadobivaju sve važnije mjesto u socijalnoj politici. Ako je u prvom poslijeratnom razdoblju porodica, bila snažan oslonac socijalne države, zbog uznapredovalih procesa, disolucije $i$ individualizacije, ona je danas sve više prisiljena transferirati svoje probleme na brigu i postupanje državi. Ako se, pritom, imaju na umu procesi kao što je starenje stanovništva i njime uvjetovana promjena međugeneracijskih odnosa, onda ima dovoljno argumenata za tvrdnju da će se u idućem razdoblju povećati utjecaj demografskih promjena na socijalnu i ekonomsku politiku, što je pretpostavka za, kako je danas popularno reći - održivi razvoj (Puljiz, 2005. c).

Da bi se izbjegli ovakvi loši trendovi, Republika Hrvatska je usvojila mjere provođenja odgovarajuće populacijske politike s elementima pronatalitetne $i$ redistribucijske politike razvitka stanovništva. Prijedlozi poticajnih mjera odnose se na jačanje materijalnog položaja porodice i pravnog i socijalnog uređenja statusa roditelja. Predloženo je proširenje prava na dječiji dodatak, te rast iznosa dodatka prema broju rođene djece, odobravaju se pronatalitetni krediti za kupnju stana ili 
izgradnju u važnim i populacijski napuštenim područjima. Za svako novorođeno dijete dobije se pravo na jednokratnu novčanu pomoć i zdravstvenu zaštitu; usklađen rad jaslica i dječijih vrtića s radnim vremenom roditelja; potom besplatno školovanje za polaznike osnovne škole što uključuje pribor i knjige i besplatni prijevoz. Za zaštitu roditeljstva i materinstva predložena je zabrana težih fizičkih radova i noćnog rada trudnicama i ženama do treće godine života djeteta, zabrana premještanja na druge poslove bez pristanka žene, te zabrana otkaza za vrijeme korištenja porodiljskog i roditeljskog dopusta. Uveden je plaćeni porodiljski i roditeljski dopust u obaveznom trajanju od 6 mjeseci, te dodatni do 12 mjeseci života djeteta, odnosno tri godine za blizance; određen je neplaćeni roditeljski dopust do treće godine života djeteta, korištenje slobodnih dana do 12. godine života djeteta $\mathrm{i}$ drugo. Predložene mjere nisu u potpunosti i prihvaćene. Neke su mjere teško provodive zbog angažiranja značajnih dodatnih sredstava iz državnog budžeta. Također i dugotrajni plaćeni porodni dopusti nisu dobro prihvaćeni u poslovnim krugovima zbog dodatnih troškova koje izdvajaju poslodavci. Ipak, dobar dio mjera je zaživio u praksi, ali nisu donijele očekivane rezultate. Natalitet nije povećan, i dalje je broj umrlih veći od broja rođenih. Već usvojene i predložene mjere populacijske politike ponajprije su usmjerene na poboljšanje materijalnog položaja porodice, tokom prvih godina života djeteta, te pomoć prilikom obaveznog školovanja.

Ukoliko ove mjere ne donesu pozitivne promjene, te se i dalje nastave negativne stope prirodnog priraštaja, uz postojeću nepovoljnu dobnu strukturu, Hrvatska će se zaista kroz nekoliko desetljeća, suočiti s ozbiljnim nedostatkom radne snage. To će se negativno odraziti na privredni razvoj, budući da su zapravo ljudski potencijali njegovi nositelji. Hrvatska bi zasigurno ostvarila veću stopu privrednog razvoja od sadašnjeg kada bi postojeći ljudski potencijali u potpunosti angažirali, te kada bi se više ulagalo u podizanje njihove kvalitete $\mathrm{u}$ skladu s privrednim zahtjevima (Bosanac, 2015).

U naučnom radu, iznosimo i pokazatelje za Federaciju Bosne i Hercegovine, s akcentom na zakonska prava koja se primjenjuju na Unsko-sanskom kantonu. Pravni propisi u oblasti socijalne zaštite uređeni su sljedećim zakonima i podzakonskim propisima: 
a) Zakon o osnovama socijane zaštite, zaštite civilnih žrtava rata i zaštiti porodice s djecom (,, Službene Novine F BiH“ 36/99)

b) Zakon o socijalnoj zaštiti, zaštiti civilnih žrtava rata i zaštiti porodice s djecom (,Službeni glasnik Unsko sanskog kantona“ br. 5/00)

c) Pravilnik o načinu obračuna isplate i postupku ostvarivanja prava na naknadu umjesto plaće ženi - majci, odnosno drugom licu u radnom odnosu za vrijeme odsustvovanja s posla radi trudnoće, poroda ili njege djeteta ("Službeni glasnik Unsko-sanskog kantona" br. 7/16).

Kantonalnim zakonom propisana su prava na: a) dodatak na dijecu, b) naknada plaće ženi, majci, u radnom odnosu, za vrijeme dok odsustvuje s posla radi trudnoće, porođaja ili njege djetcta, c) naknada porodilji za vrijemc trudnoće i poroda, za žene majke koja nisu u radnom odnosu; d) jednokratna pomoć za opremu novorođenog djeteta; e) pomoć u prehrani dijeteta i mjesečni dodatak ishrane za majke dojilje.

Budžetom za 2020. godinu, planirana je podrška demografskog razvoja Kantona, s iznosom od 200.000 KM. Vlada je u maju 2020. godine donijela, Odluku o isplati naknada za treće i svako naredno rođeno dijete u visini od $500 \mathrm{KM}$ jednokratno, a pravo na naknadu ostvaruje roditelj s prebivalištem u Unsko-sanskom kantonu.

Sva navedena prava isplaćuju se iz budžeta Unsko-sanskog kantona. Međutim, velikim djelom se kasni s isplatama. Prava koja se odnose na pomoć djeci, više imaju karakter finansijske pomoći porodicama, s jako niskim mjesečnim primanjima. Država, u ovom slučaju - kanton, finansira minimum socijalne zaštite osoba u stanju socijalne potrebe, što sigurno neće donijeti rezultate za poboljšanje demografske slike stanovništva (Ministarstvo zdravstva, rada i socijalne politike USK, 2019).

\section{POVEZANOST DEMOGRAFSKOG STARENJA STANOVNIŠTVA I SOCIJALNE POLITIKE}

Životni i radni uslovi su suština predmeta socijalne politike od njenog nastanka do današnjih dana, bez obzira na to da li se oni vide u funkciji društvenog razvoja ili kao djelatnost države. Ekonomski i politički faktori u konkretnom društvu utječu, prije svega, na ciljeve, sredstva i metode ostvarivanja socijalne politike (Lakićević, D. 1991). 
A u demografiji, za razliku od drugih oblasti, znatno je više prisutna konvencionalna kategorija (prije svega, pojmovi i kriteriji prihvaćeni od većine stručnjaka), koji se određuju na osnovu empirijskih saznanja o nekim prosječnim indikatorima starenja stanovništva.

Proces starenja stanovništva odražava se i na neke mjere, pokazatelje, kao što su: srednja (prosječna) starost, procenat ljudi u okviru stanovništva koji se definišu kao „, stari“ 60 ili 65 godina i više, odnos ljudi starijih od 60 godina prema djeci mlađoj od 15 godina, i procenat stanovništva iznad određenog broja godina, koji odgovara preostalom očekivanom životnom vijeku od 10, 15 ili 20 godina (Puljiz,2005. b).

Usto, ako i očekivana dužina života raste, srazmjerno njoj, uvećava se broj starijih u odnosu na ukupno stanovništvo, a u strukturi starijih se povećava broj izrazito starijih osoba.

Kako je socijalna politika kao praktična djelatnost dio sveukupnih djelatnosti države, a kako nauka o socijalnoj politici ima za svoj predmet proučavanja radne i životne uslove ljudi i zadovoljenje njihovih pojedinačnih i zajedničkih potreba, jasno je da je stanovništvo jedan od bitnih faktora socijalne politike.

Starenje stanovništva pogoršava odnos između radno angažovnog dijela populacije, i starih osoba. Efekat tog pogoršanja neminovno će se reflektovati na finansiranje socijalnih programa vezanih za stare, odnosno na penzijski i zdravstveni sistem. Rashodi za penzije i zdravstvo će se povećavati što zahtijeva njihovo redefinisanje, a također i definisanje novih pravaca djelovanja za poboljšanje položaja starih.

Povećanje udjela starih u ukupnoj strukturi stanovništva u razvijenim industrijskim zemljama i zemljama u tranziciji odvija se istovremeno s vrha starosne piramide (povećanje udjela starih) i od njene baze (smanjenje udjela mladih). Proces starenja stanovništva znači povećanje izdržavanog stanovništva, s obzirom na savremene karakteristike porodičnog načina života, to jest, povećanje izdataka i otvaranje čitavog niza potreba starih koje će morati da rješava socijalni sektor, konkretno oblast socijalne politike (Puljiz, 2005. b). 


\subsection{Migracija stanovništa kao važan faktor demografskih promjena}

Za socijalnu politiku, kada je riječ o demografskim procesima, značajno je pomenuti da su i migracije jedna od izraženih karakteristika koje se odvijaju iz različitih razloga, a najčešći pravci su: nerazvijena područja - razvijena područja. Zbog zakonskog uređenja socijalne politike, gdje ista nije definirana na nivou države, a u F $\mathrm{BiH}$ osnovna prava regulirana su Federalnim zakonom dok kantoni svojim zakonima uređuju oblasti socijalne zaštite gdje su propisana prava za materijalnu pomoć starim osobama, pravo na smještaj u ustanove socijalne zaštite, kao i finansiranje reguliranih prava iz budžeta kantona. Sad imamo situaciju da razvijeniji kantoni, izdvajaju znatno više sredstava za korisnike socijalnih prava, $\mathrm{u}$ odnosu na nerazvijenija područja. Iz navedenih razloga stanovnici odlaze u kantone gdje su veća novčana davanja, zdravstvena zaštita jeftinija, itd. Migracija unutar Bosne i Hercegovine jedno je od pitanja kojem treba posebno pristupiti.

Posebno treba istaći prisustvo migranata u Bosni i Hercegovini, iz zemalja Bliskog Istoka. Tačno je da su to osobe koje Bosnu i Hercegovinu smatraju državom za tranzit u zemlje zapadne Evrope, ali njihovo prisustvo sigurno otvara novo pitanje odnosa stanovništva $i$ podrške države. Naročito je prisutan veliki pritisak na oblast socijalne politike, kao što je zdravstvena zaštita osoba u tranzitu, ali i socijalna zaštita. Tačno je da se njihova prava uređuju na državnom nivou, ali migranti iz inozemstva žive u lokalnim zajednicama i oni postaju obaveza organizacije života kroz materijalnu, stambenu zaštitu na nivou općine, grada, kao i zdravstvene zaštite na nivou kantona.

Ali za demografsku sliku stanovništva Bosne i Hercegovine, posebno je važno istaći, odlazak porodica u zemlje Evropske unije. Supružnici sa svojom maloljetnom djecom, odlaze u Njemačku, Austriju, Sloveniju itd., a u državi ostaju stari, i bolesni roditelji. Jedan broj stanovnika odlazi van Bosne i Hercegovine, zapošljava se u treće zemlje, tako da određeni broj radno sposobnog stanovništva ne nastavlja finansiranje penzionih fondova, kroz međugeneracijsku solidarnost pa se uplate prema Penzionom fondu smanjuju i finansiranje istog dovodi u pitanje. Nedostatak sredstava, dovodi u pitanje isplatu penzija, što je za veći broj starih osoba, jedini izvor novčanih primanja. 
Pitanje migracija i smanjenja nataliteta je kompleksan problem za čije rješavanje je potrebno uključiti sve nivoe vlasti u $\mathrm{BiH}$, a u okviru pojedinog nivoa i sve institucije tog nivoa. Analizirajući situaciju na području Unsko-sanskog kantona, čija teritorija s najvećim djelom graniči sa Evropskom unijom, može se zaključiti da su brojni faktori koji utječu na to da stanovništvo odlazi u inozemstvo. Faktori koji motivišu stanovništvo na odlazak su u svim sferama društva su: privreda, zdravstvo, pravosuđe, obrazovanje, sigurnosna situacija i slično, stoga je potrebno raditi na unapređenju stanja u svim ovim oblastima.

Nezaposlenost, odnosno neadekvatno zaposlenje, predstavlja preovlađujući motiv za napuštanje Unsko-sanskog kantona, te bi glavne mjere u cilju sprečavanja odlaska stanovništva trebalo učiniti na ovom planu. Međutim, ne smijemo zaboraviti da je velik broj osoba koje su napustile Unsko-sanski kanton imalo relativno dobra primanja i sigurno zaposlenje. Dakle, značajne mjere bi trebalo provoditi i na unapređenju opće društvene situacije. Određene društveno neprihvatljive pojave (korupcija, nepotizam, mito itd.) se protežu kroz sve segmente društva. Sve dok se iste ne iskorijene, te dok naše društvo ne postane društvo koje nudi jednake šanse i mogućnosti za sve građane, ne možemo očekivati da će se stanje promijeniti.

$\mathrm{S}$ tim $\mathrm{u}$ vezi Unsko-sanski kanton mora provoditi, ali i vršiti koordinaciju provođenja pojedinih mjera $u$ saradnji $\mathrm{s}$ gradovima $\mathrm{i}$ općinama, te inicirati određene aktivnosti na drugim nivoima vlasti, odnosno zahtijevati njihovo provođenje. Za provođenje mjera, koje bi bile u nadležnosti vlasti Unsko-sankog kantona, bilo bi neophodno formirati određeno radno tijelo koje bi pratilo provođenje ovih mjera, te koje bi obavještavalo Vladu USK i Skupštinu USK o realizaciji istih. Također, na nivou gradova i općina bi bilo potrebno formirati određena radna tijela koja bi pratila provođenje pojedinih mjera na ovom nivou, putem kojih bi se vršila koordinacija s kantonalnim nivoom vlasti. Jedino se takvim sektorskim pristupom, uključenošću i saradnjom apsolutno svih institucija, može pomoći u stabilnosti ili čak u poboljšanju demografske slike stanovništva (Ministarstvo zdravstva, rada i socijalne politike USK, 2019). 


\subsection{Odnos populacione i socijalne politike u Bosni i Hercegovini}

Socijalna i populaciona politika su međusobno povezane, isprepletene i djeluju zajednički. Stoga, bez obzira na rezultate populacione politike, koji uglavnom nisu doprinijeli mijenjanju stanja u povoljnom pravcu, usljed veoma složene determinističke osnove nedovoljnog rađanja, može se zaključiti da demografski procesi predstavljaju sve složenije pitanje koje socijalna, populaciona i druge politike trebaju (u budućnosti) da rješavaju.

Populaciona politika je niz mjera i akcija koje provodi određena država prema svome stanovništvu, pritom djelujući na konkretne varijable. Između ostalog, najčešće se djeluje na stopu porasta stanovništva. Bosna i Hercegovina je, nažalost, bila pogođena ratom i upravo je njime pokrenut proces depopulacije koji je već bio i otpočeo. Stvoreni su ogromni demografski gubici koji se dijele na stvarne (broj poginulih, iseljenih, umrlih) i čiste. Nadalje, čisti demografski gubitak je taj da je u ratu sudjelovalo radno sposobno i reproduktivno stanovništvo, koje je tim činom bilo spriječeno sudjelovati u procesu reprodukcije. Još jedan fenomen vezan za rat je mobilizacija srednje generacije koja nije bila $\mathrm{u}$ braku, s obzirom na to da se rat odužio pa mnogi od njih nisu stupili $u$ brak te je i tu izostao onaj neophodni natalitet. Osim toga, činjenica je da svaki rat prati velika emigracija, a na području Bosne i Hercegovine, pospješio je i pražnjenje ruralnih područja.

U Bosni i Hercegovini došlo je do prirodnog smanjenja stanovništva, s tim i depopulacije stanovništva, određenog područja. Posljedice su dugoročne i teške. Starenjem stanovništva, stari i kontingent fertilno sposobnog stanovništva, smanjuje se stopa nataliteta. Znamo da je 1991. godine prirodni prirast bio 7,8 dok je 2007. godine bio je 0,3 (Dugandžić, 2015).

\subsection{Donošenje dokumenata za strateški razvoj}

Da bi se u Bosni i Hercegovini postigla ravnoteža, između socijalne (potrebe) i ekonomske politike (prihodi), neophodno je definirati šta je prvi korak u ovim nastojanjima.

Vlada i Parlament $\mathrm{F} \mathrm{BiH}$, donosi Strategiju razvoja $\mathrm{F} \mathrm{BiH,} \mathrm{koja} \mathrm{je}$ nastala u periodu kada je u $\mathrm{BiH}$ započet proces implementacije ciljeva održivog razvoja iz Agende UN 2030. i izrada Strategije pametne 
specijalizacije. Također, u ovom periodu je usaglašena i Reformska agenda 2, kao nastavak socioekonomskih reformi koje su započete još 2015. godine. U maju 2019. g. završen je Upitnik evropske komisije pa su našoj državi dostavljene preporuke za unapređenje u različitim oblastima. Svi nabrojani dokumenti su u potpunosti uključeni u Strategiju i vidljivi su u tekstu što će biti veoma važno u narednom periodu prilikom izvještavanja o implementaciji.

\section{Okvir implementacije Strategije}

Fokusiranje Strategije razvoja F BiH (2021-2027) na ciljeve održivog razvoja, tj. Agendu 2030, odvija se u okviru određenog konteksta koji je pod utjecajem ključnih pokretača i ograničenja. Navodimo ih ovdje ukratko s fokusom na trendove vezane za: 1.) Stanovništvo, 2.) Migracije, obrazovanje i ljudski kapital, 3.) Ekonomski rast i zapošljavanje, 4.) Socijalnu zaštitu, koheziju, nejednakost, siromaštvo i ranjivost, 5.) Javni sektor, javne finansije i javne kompanije, 6.) Upravu, vladavinu prava i ljudska prava.

Stanovništvo BiH se smanjuje i stari zbog niske stope fertiliteta i snažne emigracije. Veličina stanovništva $\mathrm{BiH}$ spustila se na 3,5 miliona 2018. godine. UNDESA (United Nations Department of Economic and Social Affairs) projekcija pokazuju da će broj stanovnika pasti ispod 2,3 mliona, do 2100. godine.

Važni su i podaci u vezi sa ženama - u prosjeku rađaju 1,3 djece, značajno ispod 2,1 djece nužnih za očuvanje veličine stanovništva (Trendsin International Migrant Stock: 2017).

Posebno navodimo demografsku sliku koja očekuje Bosnu i Hercegovinu u doglednoj budućnosti. Ne možemo se ne osvrnuti na postojeću demografsku sliku koja je rezultat, prije svega, provođenja loše ekonomske politike. U Bosni i Hercegovini će se nastaviti pad stope nataliteta i fertiliteta. Nastavit će se emigracije radno sposobnog i fertilno sposobnog stanovništva.

Ističemo da je dosadašnji trend demografskih kretanja, broja stanovništva u trećoj životnoj dobi, negativne implikacije na daljnji društveno-ekonomski razvoj u Bosni i Hercegovini očit, a potreba za adekvatnim populacijskim mjerama od lokalnog do globalnog nivoa je nužna i hitna. Sagledavajući jako lošu demografsku sliku 
bosanskohercegovačkog stanovništva, važno je naglasiti i da sve vrste medija uključe u programe zaštite kao obavezni saradnici, s naglaskom na istraživačko novinarstvo. Poseban akcenat mora da se stavi na popularizaciju i animiranje lokalne društvene zajednice, da se aktivnije uključi u rješavanje zajedničkih problema osoba u stanju socijalne potrebe, među kojima su stare osobe. Lokalna zajednica mora da brine o stanovništvu, da bi opstala, trajala i razvijala se. Stanovništvo mora biti u opciji organa zajednice, kao što je to prostor i njegovo uređenje i kao što su to sektori ekonomske i socijalne politike. Lokalna zajednica mora definirati svoju populacionu politiku, da bi preduprijedila poremećaje, odnosno da bi ih zaustavila, kada postoje.

Sve navedeno upućuju na sadržaj i ciljeve aktivnosti u razvoju socijalne politike s posebnim uvidom na demografska kretanja stanovništva. Da bi bili uspješni, moraju da se baziraju na istraživanjima tj. na empirijskim pokazateljima, potrebama koje su utvrđene na metodološki korektan način, organizovanim i prikazanim u korektnim, naučno analitičkim cjelinama koje su povezane s konkretnim programskim zadacima koje država Bosna i Hercegovina mora, ne samo donijeti, nego i implementirati.

\section{ZAKLJUČCI}

- Predmet demografije je stanovništvo koje živi na nekoj teritoriji i koje se mijenja u pogledu svojih obilježja po zakonomjernostima, svojstvenim za izvjesno historijsko razdoblje. Stanovništvo predstavlja skup ljudi na nekoj teritoriji koji se razlikuje od samih individua, mada je od njih sastavljen. Po današnjem, širem gledištu, demografija izučava, njegovo kretanje, razmještaj i druge pojave, kao i njegove strukture koje se zasnivaju na individualnim karakteristikama pojedinaca.

- U demografskim procesima, značajno je spomenuti da su migracije stanovništva jedna od izraženih karakteristika koje se odvijaju iz različitih razloga, a najčešći pravci su:

a) nerazvijena područja - razvijena područja, gdje imamo situaciju da razvijeniji kantoni izdvajaju znatno više sredstava za korisnike socijalnih prava, u odnosu na nerazvijena područja. Iz navedenih razloga stanovnici odlaze u kantone gdje su veća novčana primanja, 
zdravstvena zaštita jeftinija i tako predstavljaju važan faktor u oblasti socijalne politike;

b) cijele porodice odlaze van Bosne i Hercegovine, zapošljavaju se u treće zemlje, te samim tim određeni broj radno sposobnog stanovništva ne nastavlja finansiranje penzionih fondova, kroz međugeneracijsku solidarnost, tako da se uplate prema Penzionom fondu smanjuju i finansiranje istog dovodi u pitanje;

c) prisustvo migranata u Bosni i Hercegovini, iz zemalja Bliskog Istoka, otvara novo pitanje odnosa stanovništva i podrške države. Tačno je, da su njihova prava regulisana na državnom nivou, ali migranti iz inostranstva žive u lokalnim zajednicama i oni postaju obaveza organizacije života kroz materijalnu, stambenu, zdravstvenu zaštitu na nivou općine i kantona.

Sva navedena migraciona kretanja stanovništva, a koja su navedena $\mathrm{u}$ ovom radu, zahtijevaju empirijska istraživanja koja se trebaju provesti na cijelom području Bosne i Hercegovine, a sve s ciljem istraživanja uzroka, zbog kojih dolazi do migracije stanovništva te posljedice koje će migracije ostaviti na demografsku strukturu stanovništava i socijalnu politiku države.

- Sve vrste medija moraju da se uključe u programe zaštite kao obavezni saradnici s naglaskom na istraživačko novinarstvo. Poseban akcenat mora da se stavi na popularizaciju i animiranje lokalne društvene zajednice da se aktivnije uključi u rješavanje zajedničkih problema osoba u stanju socijalne potrebe, među kojima su stare osobe u jako velikom broju.

- Stanovništvo, njegova starosna struktura, radna sposobnost, natalitet i mortalitet, predstavljaju osnovne pokazatelje mogućnosti i ekonomskog razvoja, a samim tim pravca socijalne politike neke države. Socijalna i populaciona politika su međusobno povezane, isprepletene i djeluju zajednički. Važno je naglastiti da demografski procesi predstavljaju sve složenija pitanja koja socijalna, populaciona i druge politike treba u budućnosti, da rješavaju. Važno je naglasiti da ključni demografski procesi, uključujući promjene u porodici, odlazak mladih u zemlje Evrope, ostanak starih roditelja, zadobivaju sve važnije mjesto u socijalnoj politici. Ako je u prvom poslijeratnom razdoblju porodica bila snažan oslonac socijalne države, zbog uznapredovalih 
procesa, disolucije i individualizacije, ista je danas, sve više prisiljena transferirati svoje porodične probleme, na brigu i postupanje državi.

Na području Unsko-sanskog kantona, čija teritorija s velikim dijelom graniči s Evropskom unijom, postoje brojni faktori koji utječu da stanovništvo odlazi u inozemstvo. Faktori koji motivišu stanovništvo na odlazak su u svim sferama društva - privreda, zdravstvo, pravosuđe, obrazovanje, sigurnosna situacija i slično. Zato je potrebno raditi na unapređenju stanja u svim ovim oblastima. Značajne mjere bi trebalo provoditi i na unapređenju opće društvene situacije. Određene društveno neprihvatljive pojave (korupcija, nepotizam, mito itd.) se protežu kroz sve segmente društva. Sve dok se iste ne iskorijene te dok naše društvo ne postane društvo koje nudi jednake šanse i mogućnosti za sve građane, ne možemo očekivati da će se stanje promijeniti.

Može se izvesti zaključak, da bosanskoshercegovačkom društvu predstoji niz reformi u dijelu socijalne i drugih politika usmjerenih na rješavanje potreba sve većeg broja starih osoba, u godinama koja dolaze, uz aktivno učešće naučnika iz područja demografije i socijalne politike.

\section{LITERATURA}

1. Bosanac, S. (2015) „Utjecaj procesa demografskog starenja nagospodarska kretanja " Sveučilište Jurja Dobrile u Puli.

2. Despot Lučanin J. (2003) ,Iskustvo starenja - Doprinos teoriji starenja “, Zagreb: Naklada Slap, 238. str.

3. Dugandžić, Ž. „BIH je potrebna službena populaciona politika“, Sveučilište u Mostaru. (internet: preuzeto 1. 10. 2018).

4. Lakićević, D. (1991) „Socijalna politika“ Beograd: Savremena administracija.

5. Milosavljević, M. (1990) „Socijalni rad na raskršću“, Beograd: Naučna knjiga.

6. Miković,M. ( 2005) „Osnove socijalne politike „,, Magistrat, Sarajevo.

7. Ministarstva zdravstva, rada i socijalne politike USK, (2019) „Informacija sa prijedlogom mjera za zaustavljanje iseljavanja stanovništva i porast nataliteta ", Vlada Unsko-sanskog kantona, Bihać.

8. Puljiz, V., Bežovan, G., Šućur, Z., \& Zrinščak, S. (2000) „Sustavi socijalne politike“: Studijski centar socijalnog rada Pravnog fakulteta, Zagreb. 
9. Puljiz, V. (2005.a) „Hrvatska slijedi evropsku demografsku sudbinu“, Le Monde diplomatique.

10. Puljiz, V. (2005.b) „Socijalna kohezija pred demografskim izazovima“, Evropska konferencija o stanovništvu 2005. Vijeće Evrope. Strazburg. 7-8 aprila 2005. Revija za socijalnu politiku, 12(2); 257-261.

11. Puljiz, V. ( 2005. c)“ Demografske promjene i socijalna politika“, Studijski centar socijalnog rada Pravnog fakulteta, Zagreb (preuzeto:www.pilar.hr. 27. 10. 2020).

12. Puljiz, V. (2015),Starenje stanovništva-izazov socijalne politike: Studijski centar socijalnog rada Pravnog fakulteta, Zagreb.

13. Trendsin International Migrant Stock: (2017) „, Revision Documentation".

14. Šarić, H., Družić, S. i dr. (2016) „Socijalna gerontologija“ , OFF-SET, Tuzla

15. Živić, D., (2003),Demografske odrednice i posljedice starenja stanovništva Hrvatske“, Institut društvenih znanosti Ivo Pilar Zagreb, Hrvatska.

16. Wertheiner-Baletić (1999) „Stanovništvo i razvoj“, Mate - Zagreb, Biblioteka Gospodarska misao, Zagreb, str. 655.

17. www.ekof.bg.ac.rs/wp.../2014/.../“Demografska-analiza ,-- (preuzeto 27.10.2020).

18. www.fzzpr.gov.ba - „Strategija razvoja FBiH 2021-2027.“ - preuzeto: 27. 10. 2020. 


\author{
Dr.sci. Sena Družić, Assistant Professor \\ Government of Una-Sana Canton \\ Email:sena_druzi@@yahoo.ca
}

\title{
DEMOGRAPHIC AGING OF THE POPULATION AND SOCIAL POLICY
}

\section{Summary}

Demography investigates and studies the laws and regularities in the biological and migratory movement of the population, as well as changes in demographic structures, and determines the interrelationships of the movement of the population with other social and economic phenomena. In this scientific paper, the subject of research is the elderly population, which is a specific social group whose needs stem from the aging process, and appear in the field of social policy, as an organized, active engagement of the community in providing living conditions, i.e. social safety of the elderly. The aim of this paper is to find out how much migratory movements of the population, at the local level (ruralurban), emigration of entire families abroad, as well as the transit of residents from the Middle East and other countries through our country, affect the changing demographic structure of Bosnia and Herzegovina. The paper uses the method of content analysis, with available data, on the subject. Based on the findings of the paper, it is concluded that a marked decrease in the number of newborns, and an increase in the number of elderly people, as well as population migration, which occurs in our country, require empirical research, which would be conducted throughout in the territory of Bosnia and Herzegovina, all with the aim of understanding the causes, due to which migration of the population occurs, and the consequences that migration will leave, on the demographic structure of the population and the social policy of the state.

Key words: demography, aging, population aging, social policy 
الدكتورة المحاضرة سينا دروشيتش أشكانش

حكومة منطقة أونسكو-سانسكي

E-mail: sena_druzic@yahoo.ca

\section{شيخوخة السكان الديمغرافية والسياسة الاجتماعية}

\section{الخلاصة}

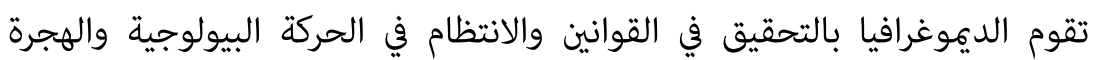

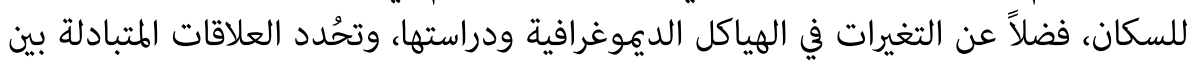

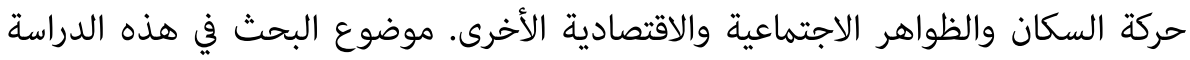

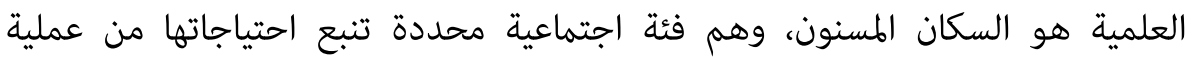

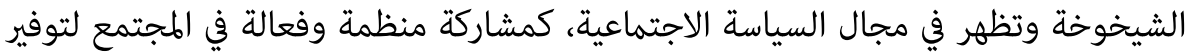
الظروف المعيشية للمسنين وسلامتهم الاجتماعية.

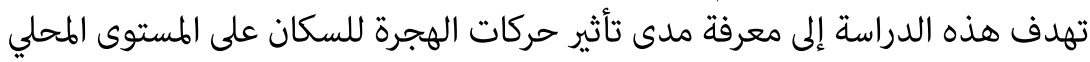

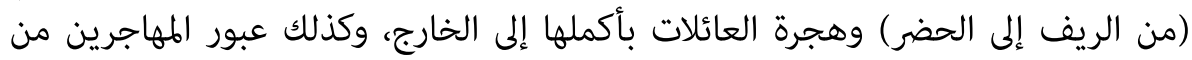

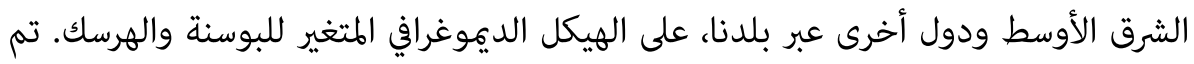

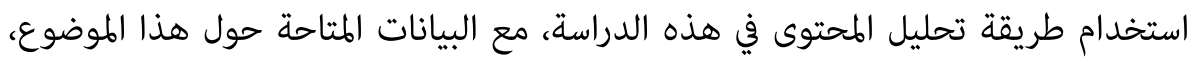

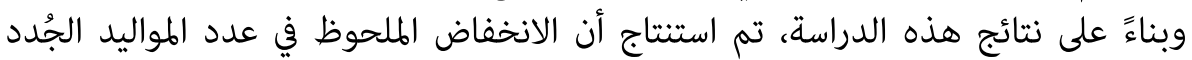

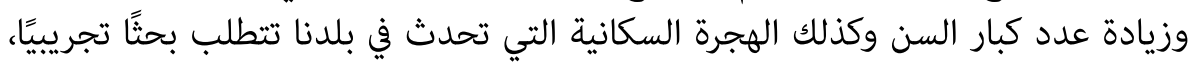

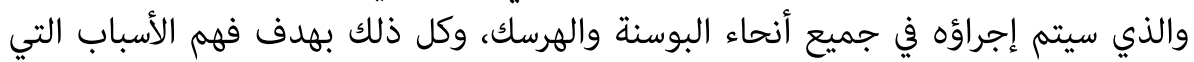

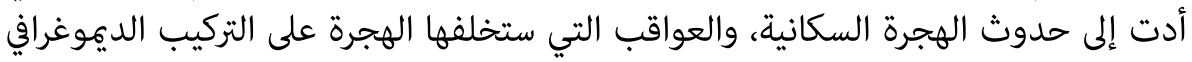
للسكان والسياسة الاجتماعية للدولة.

الكلمات المفتاحية: الديموغرافية، الشيخوخة، السكان، السياسة الاجتماعية. 